\title{
DENDROMETRIC CHANGES AS WATER STRESS INDICATOR FOR SUNFLOWER (HELIANTHUS ANNUS L.) AND MAIZE (ZEA MAYS L.) - BASIC RESEARCH IN LABORATORY CONDITIONS
}

\author{
Martina Kováčová凶, Viliam Bárek, Vladimír Kišš \\ Faculty of Horticulture and Landscape Engineering, Slovak University of Agriculture in Nitra, Tulipanova 7, 949 76, Nitra, Slovakia
}

\begin{abstract}
Aim of the study

The physiological impact of drought on the crop is reflected in the dendrological changes of the tree or plant body. In this study, we installed automatic dendrometers and we investigated the effect of irrigation dose at different intervals on the growth of sunflower and maize in laboratory conditions.
\end{abstract}

\begin{abstract}
Material and methods
For our research, we have chosen sunflower (Helianthus annus L.) and maize (Zea Mays L.) sown in a laboratory equipped with Mars Hydro 400 LED lights as a substitute source of natural sunlight for 12 hours. Both crops were divided into containers A (irrigation dose of $5 \mathrm{~mm}$ was applied each day) and B (the same irrigation dose was applied at a 3-day interval). In every container, we have measured volumetric soil water content with 10HS sensors (by Decagon Devices) and dendrometric measurements of plants diameter with DD-S sensors (by Ecomatik).
\end{abstract}

\begin{abstract}
Results and conclusion
A comparison of sunflower and maize irrigated at different intervals showed an increase in the diameters of stems at 1-day irrigation compared to 3-day by $0.8 \mathrm{~mm}$ (sunflower) and $12.0 \mathrm{~mm}$ (maize). The growth of plant mass was continuous at 1-day irrigation with minor fluctuations during the alternation of the dark and light phases. During the 3-day irrigation, greater shrinkage of the stems occurred, indicating the onset of water stress for the crops. The results of the work can be the basis for determining the appropriate application of irrigation bag in conditions of changing climate.
\end{abstract}

Keywords: dendrometer, sunflower, maize, drought, water stress

\section{INTRODUCTION}

Since the beginning of the twentieth century, the average global temperature has risen by more than $1^{\circ} \mathrm{C}$, with most of the warming happening over the last 50 years. In addition to the melting of glaciers or the rise of ocean levels, this very rapid warming brings several other changes in the natural environment, which are less obvious at first glance, but they are nevertheless serious and very complex (Pecho, 2020). Heat waves posed the greatest meteorological risk in the period 2015-2019. Their impacts affected all continents and led to setting new temperature records. Heat waves and subsequent droughts have led to significant loss of life, intensification of forest fires, as well as crop losses (Pecho and Markovič, 2019). Čimo et al.

凶e-mail:m.tinkakovacova@gmail.com 
(2020) showed prolongation of vegetation period of some vegetables due to higher air temperature in Slovakia. Based on three case studies, Szwejkowski et al. (2017) forecasted that non-precipitation periods above 10-days can have impact on vegetation periods mostly in the spring period, what can lead to extension of the current vegetation period almost by four months.

Drought is a physiological form of water deficit where soil water available to the plant is inadequate, which adversely affects the plant's metabolism (Kumar et al., 2018). Water stress or water deficit has substantial part in low crop production in significant agricultural crops. With ongoing climate change, drought is a common abiotic stress and has a significant negative impact on growth and grain yield (Deng et al., 2018).

At this point it is important to mention that the physiological impact of drought on the crop is reflected in the dendrological changes of the tree or plant body. Decreasing soil water content has impact on the water content in plants. The physiological sign of water stress is observed as slower growth or withering (Švihra and Kleňová, 2011).

In the present study, we installed DD-S automatic dendrometers (by Ecomatik) and we investigated the effect of irrigation dose at different intervals on the growth of agricultural crops - sunflower (Helianthus annus L.) and maize (Zea Mays L.) in laboratory conditions.

\section{MATERIALS AND METHODS}

Our research was conducted in the laboratory of the Slovak University of Agriculture in Nitra. It was equipped with Mars Hydro 400 LED lights, as a substitute source of natural sunlight, activated for 12 hours. Those lights cover the spectrum from $440 \mathrm{~nm}$ to $730 \mathrm{~nm}$. For growth, it is the blue spectrum $(450-500 \mathrm{~nm})$ and the red spectrum $(620-680 \mathrm{~nm})$ that are the most important (Mars Hydro, 2020). Air temperature in the laboratory was in the range of $22{ }^{\circ} \mathrm{C}$ to $25{ }^{\circ} \mathrm{C}$. Air moisture during our experiment was in the range of $55 \%$ to $65 \%$. Crops were sown into containers and filled with professional growing peat substrate of white and black peat. It is highly enriched with essential nutrients and trace elements in a chelated form with slightly acid pH 5.5-6.5.

For our research, we have chosen sunflower (Helianthus Annus L.) and maize (Zea Mays L.). Sunflower is considered thermophilic. The plant has the greatest heat demand during the period of generative organ formation. During the vegetation period it requires 400 $500 \mathrm{~mm}$ of precipitation. It is most sensitive to a lack of soil moisture until the flowering period (Uher et al., 2016). The height of the plant in our climate conditions is around $2 \mathrm{~m}$, but under favourable climate conditions, it can grow up to $4 \mathrm{~m}$ (Elsheikh, 2015). Maize is a thermophilic plant. In Slovakia it is grown in areas with an average annual air temperature of $9-10{ }^{\circ} \mathrm{C}$. Maize uses sunlight very well. A short light day speeds up flowering but reduces the number of flowers and the height of the plant. Maize is water-intensive, although it manages water well. Good use of moisture is guaranteed by the suction power of the root (Uher et al., 2016).

Both sunflower and maize were divided into containers A and B. An irrigation dose of $5 \mathrm{~mm}$ was applied to container A each day. In container B, the same irrigation dose was applied at 3-day interval. Drip irrigation was provided by Auto Dosing Pump DP-6 (ATI).

\section{Dendrometric and soil moisture measurement}

In our research we used dendrometric devices by Ecomatik, of Dendrometer Diameter - Small type (DD-S). Those are designed specifically for installation on agricultural plants, small trees and branches. This is suitable for plants with a diameter of less than $50 \mathrm{~mm}$, such as wheat, maize, or sunflower. Due to the weight of only 13 grams and the required calibration, sensors had no negative impact on the recorded data nor did they cause any damage to the plants. The precision of the sensor is $\pm 1,5 \mu \mathrm{m}$ (Ecomatik, 2020). Dendrometric measurements were automatically recorded every hour to Dendrometer Datalogger type DL-18. The raw data from the logger has units in Volt, therefore, to get micrometre values for DD-S type dendrometer, the following formula is used (Ecomatik, 2020):

$$
\text { Micrometre }=\text { raw data }(\mathrm{V}) \times 4400
$$

For the whole research period, it was important to have an overview of the soil moisture values as well. For this purpose, were used soil water content sensors ECH2O 10HS developed by Decagon Devices. Sensor prongs are embedded in the soil, which enables us to measure the dielectric constant of the soil using the 

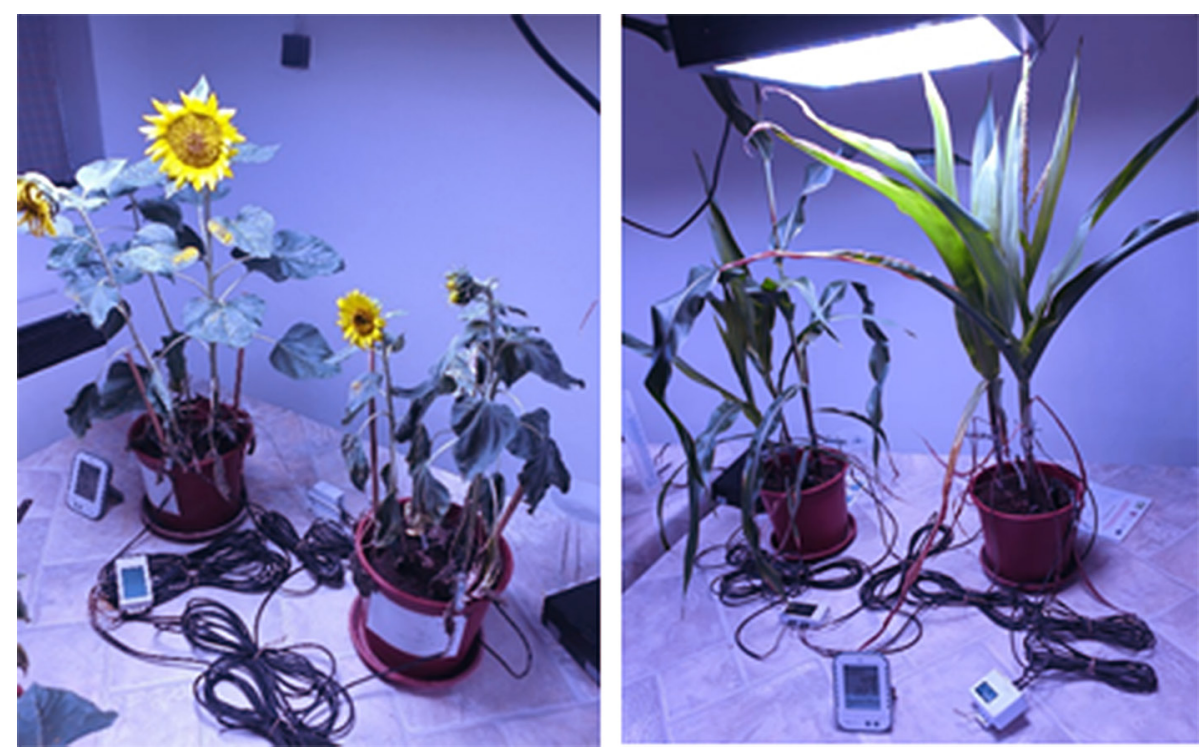

Fig. 1. Dendrometric and soil measurements on sunflower (Helianthus annus L.) and maize (Zea Mays L.) (Kováčová, 2020)

technology of capacitance and frequency domain as a source to calculate volumetric water content (Meter Group, 2020).

\section{RESULTS AND DISCUSSION}

We started our research by sowing the seeds of sunflower on 24.10.2019. We did not monitor any growth changes or irrigation dose, because the vegetation stages of germination and establishment of seedling were not significant for our study. After 30 days of growth, the sunflower advanced to vegetation stage of leaf elongation and crop development. We installed the dendrometric sensors on the plants in containers A and $\mathrm{B}$ on day 37 from sowing the seeds. Those sensors were placed on the experimental subject during whole research period until day 59 (21.12.2019).

When comparing 1-day and 3-day irrigation, we saw differences in diameter, and thus in plant size. Sunflowers irrigated with a dose of $5 \mathrm{~mm}$ increased by $1.6 \mathrm{~mm}$ each day from the beginning of the measurements and maintained this diameter with less fluctuations until the end of the measurements. Sunflowers irrigated with a dose of $5 \mathrm{~mm}$ grew by only $0.8 \mathrm{~mm}$ every third day and shrinkage of the stems by $0.6 \mathrm{~mm}$ was observed (see: Fig. 2).

After 4 days from the start of measurements (day 41 from planting), an increase in diameter of $0.5 \mathrm{~mm}$ is visible compared to 3-day irrigation. The fluctuation of the diameters is minimal and is caused by the

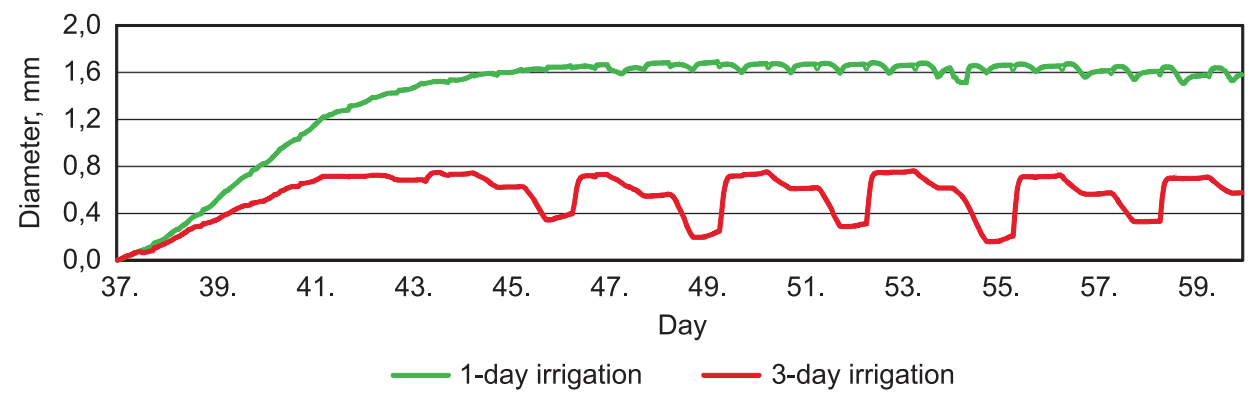

Fig. 2. Comparison plants with 1-day and 3-day irrigation - sunflower (Helianthus annus L.) 
transpiration of the plants. While the LED lights were on, the vents were opened and water from the plant cells was being transposed. Subsequently, during the off phase, the vents were closed, and the plants replenished the cells through the root system. Also, the soil moisture fluctuated in the range of $5-10 \%$, but no large fluctuations occurred during the measurement (see: Fig. 3).

With 3-day irrigation, the increase in diameters is half as low as with 1-day irrigation, and fluctuations in diameters of $0.6 \mathrm{~mm}$ are observed, which can be considered as a result of the deficit of water in the plant and subsequent water stress. After the irrigation dose, an increase in soil moisture up to $10-15 \%$ is observed. Each time the irrigation is delivered, the diameter of the stems also increases, and it starts to decrease again after a few days due to a lack of water (see: Fig. 4).

We determined the dependence between dendrometric changes and soil moisture by statistical analysis. It can be seen from Figure 5 that the larger the diameter of the sunflower, the lower the soil moisture, even though it was irrigated every day. The coefficient of determination was determined by linear regression. This coefficient gives an idea of how many data points fall within the results of the line formed by the regression equation. The higher the coefficient, the higher percentage of points the line passes through when the data points and the line are plotted. In this case, the dependence of dendrometric changes on soil moisture is 54\% (see: Fig. 5).

At 3-day irrigation, the dependence of dendrometric changes on soil moisture represents a cluster of points from which it is difficult to determine the dependence, as the increase of stem diameter was only tenths of a millimetre during the study period and it increased after the irrigation dose, otherwise the stems gradually shrunk. Using the linear regression trend, the coefficient $\mathrm{R}^{2}=0.32$ was found, which means a $32 \%$ dependence (see: Fig. 6).

We started our research by sowing the seeds of maize on 23.09.2019. We also did not monitor any growth changes or irrigation dose during the vegetation stages of germination and establishment of seedling. We installed the dendrometric sensors onto the plants in container A and the plants in container B on day 48. Those sensors were placed on the experimental subject during whole research period until day 67 (27.11.2019).

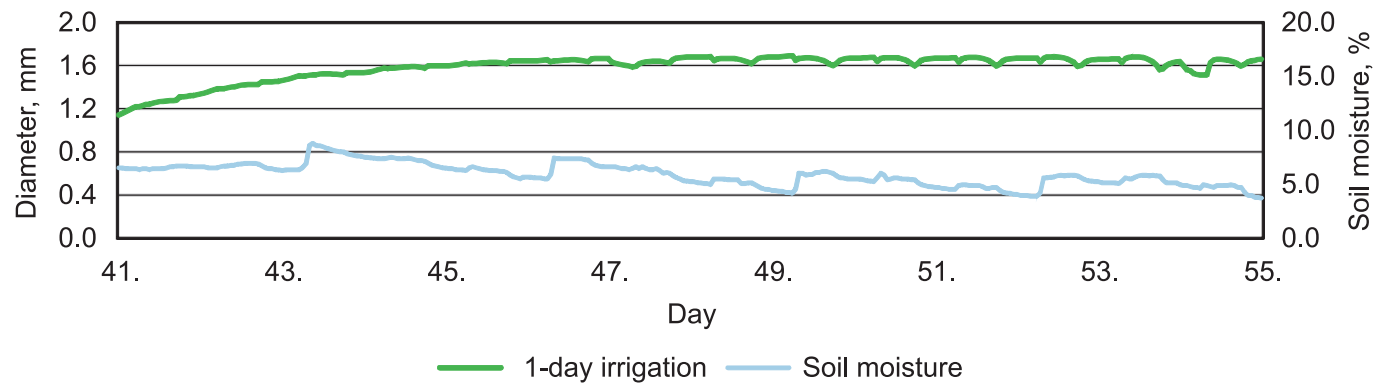

Fig. 3. Comparison of dendrometric and soil measurements for 1-day irrigation - sunflower (Helianthus annus L.)

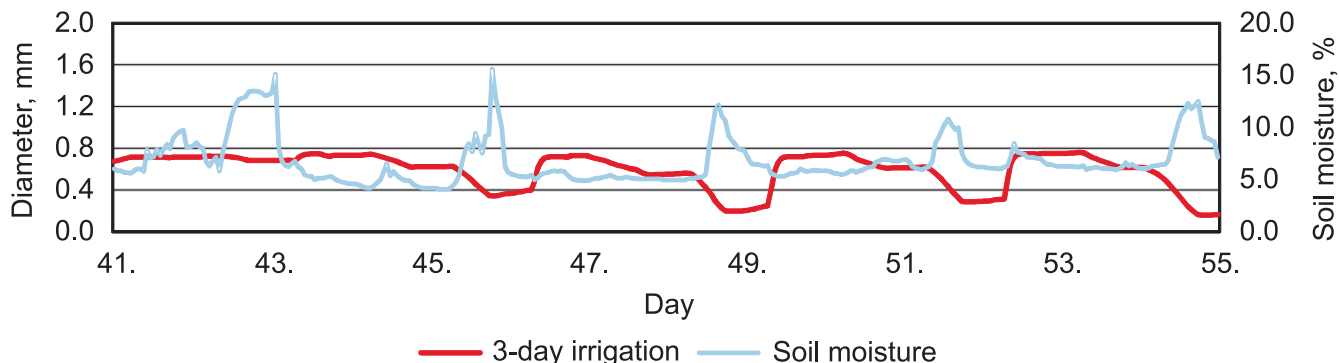

Fig. 4. Comparison of dendrometric and soil measurements for 3-day irrigation - sunflower (Helianthus annus L.) 
As with sunflower, maize with 1-day irrigation had a higher increase in stem diameters. Since the start of measurements on day 48 , the diameter has increased by more than $12 \mathrm{~mm}$. The diameter of maize irrigated at 3-day interval from the beginning of the measurements increased by only $1 \mathrm{~mm}$ and in certain phases of growth it reached smaller diameters than at the beginning of the measurements. Significant fluctuations in diameters are also observed, due to water shortages (see: Fig. 7).

A more significant increase in stem diameters occurred from day 53. Small fluctuations during dendrometric measurements are caused by water transpira- tion in plants. The soil moisture gradually decreased from $25 \%$ to $5 \%$, which is explained by the increase in plant mass, the substrate used and the irrigation dose of $5 \mathrm{~mm}$ (see: Fig. 8).

The values of maize averages at 3-day irrigation did not change significantly. The maximum increase was $1 \mathrm{~mm}$, but there were often periods with shrinkage of the stem even below the initial level of measurements. The increase always occurred after the application of the irrigation dose, but immediately after, the decrease in averages began. We can define it as the onset of water stress or water deficit. Soil moisture was in the range of 5-10\% (see: Fig. 9).

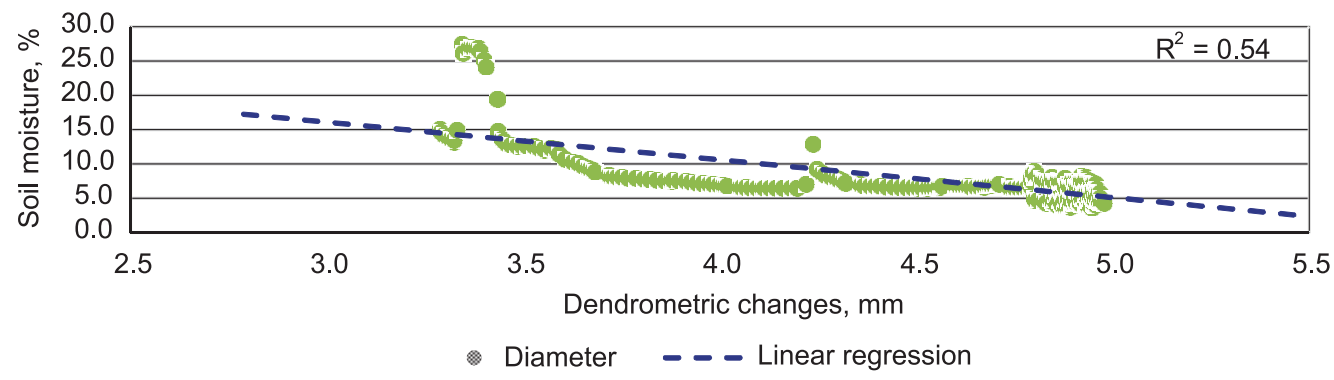

Fig. 5. Dependence of dendrometric changes on soil moisture for 1-day irrigation - sunflower (Helianthus annus L.)

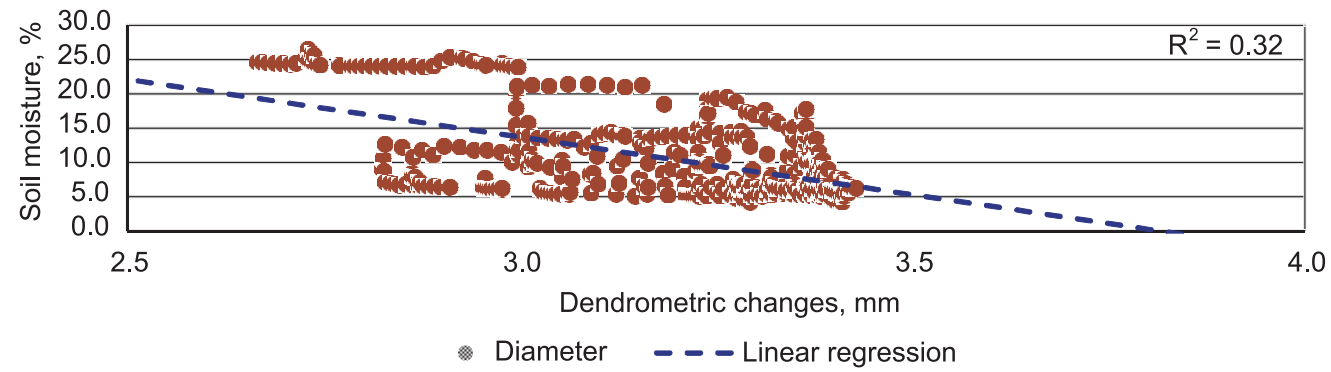

Fig. 6. Dependence of dendrometric changes on soil moisture for 3-day irrigation - sunflower (Helianthus annus L.)

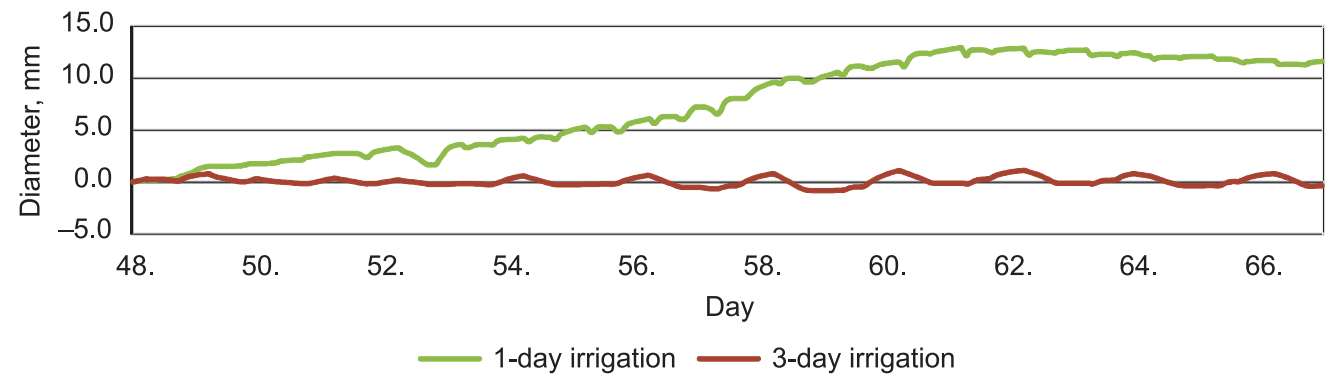

Fig. 7. Comparison of plants with 1-day and 3-day irrigation interval - maize (Zea Mays L.) 


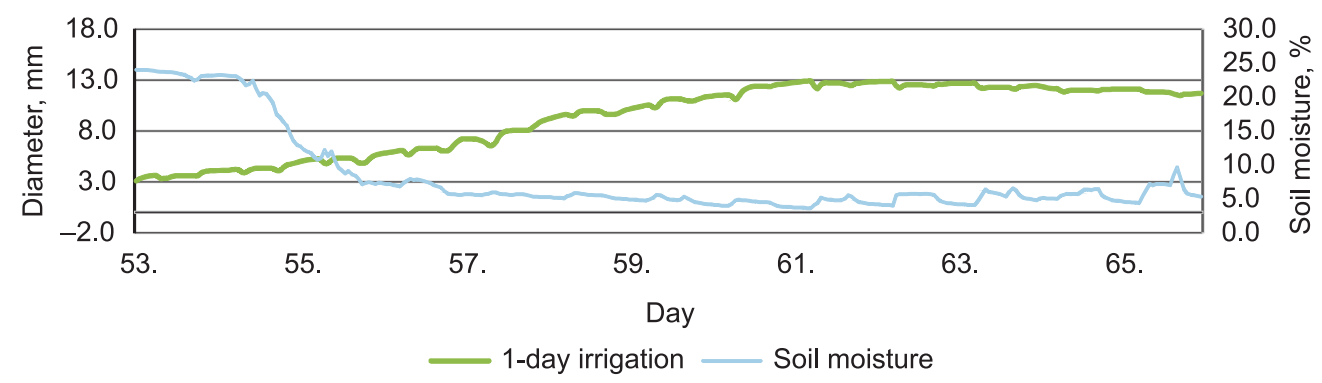

Fig. 8. Comparison of dendrometric and soil measurements for 1-day irrigation interval - maize (Zea Mays L.)

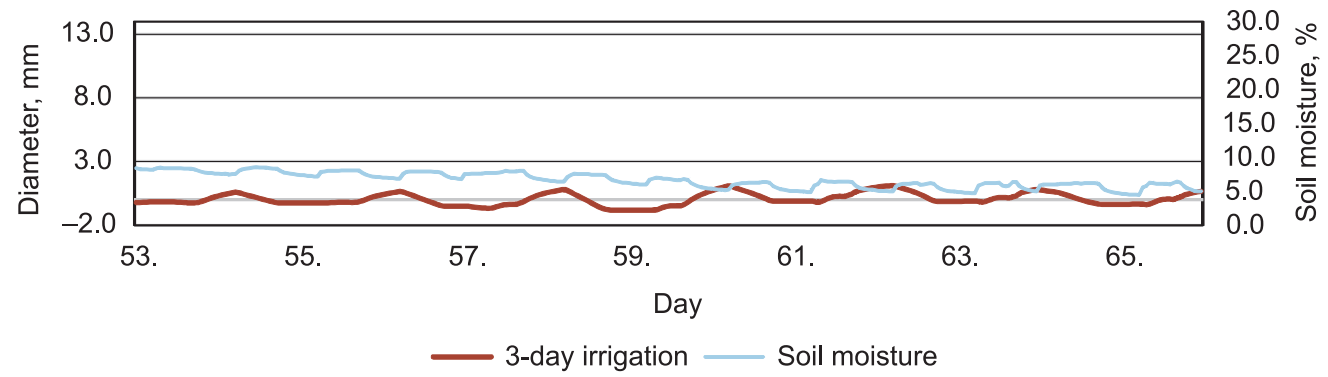

Fig. 9. Comparison of dendrometric and soil measurements for 3-day irrigation interval - maize (Zea Mays L.)

Linear regression for maize showed a dependence of up to $77 \%$, as can be seen in Figure 10. Stem diameters increased rapidly during 1-day irrigation. Maize needed enough water for growth, and therefore the soil moisture decreased continuously, despite the daily irrigation.

As with sunflower, for maize irrigated at 3-day intervals, it is difficult to determine any correlation between dendrometric changes and soil moisture. Maize has shown almost no increase since the start of the measurements and the relevant effect of dendrometric changes from the soil moisture cannot be determined. The coefficient of determination is only $13 \%$, which is very low (see: Fig. 11).

One method of early detection and monitoring of water stress is to measure changes in trunk diameter using dendrometers. Studies of temporal dynamics of water consumption have pointed to strong correlations of this consumption with radiation balance, saturation deficit, and bioclimatic coefficients of the agricultural crops (Hus and Paganová, 2018; Mazhayskiy et al., 2020).

In this way, it is possible to identify the growth and physiological response of trees to seasonal cli- matic conditions. Chitu et al. (2012) used this method on irrigated apple trees (Malus domestica Borkh.) cultivars Redix and Braeburn in the south of Romania between 2009 and 2012. It has been found that indicators of changes in trunk diameter include for example maximum daily withdrawal, daily recovery, and daily growth of the tree trunk between two consecutive days. Hermann et al. (2016) installed dendrometers at four different wooded sites to determine how perimeter of the tree changes over time and how dynamics relate to environmental conditions. Daily dynamics of stem circumference showed daily shrinkage due to transpiration and amount of water in tree cells. The objective of Fernández et al. (2008) was to better understand the usefulness of fruit dendrometers in assessing water stress, and to evaluate its application in scheduling the regulated water deficit in olive orchards. They compared fruit dendrometers with other sensors previously used as water stress indicator and with traditional measurements such as midday leaf water potential to assess their applicability. Von Känel et al. (2019) measured that changes in the diameter of plant stems occur not only due to their growth, but also due to changes in the water content within the 


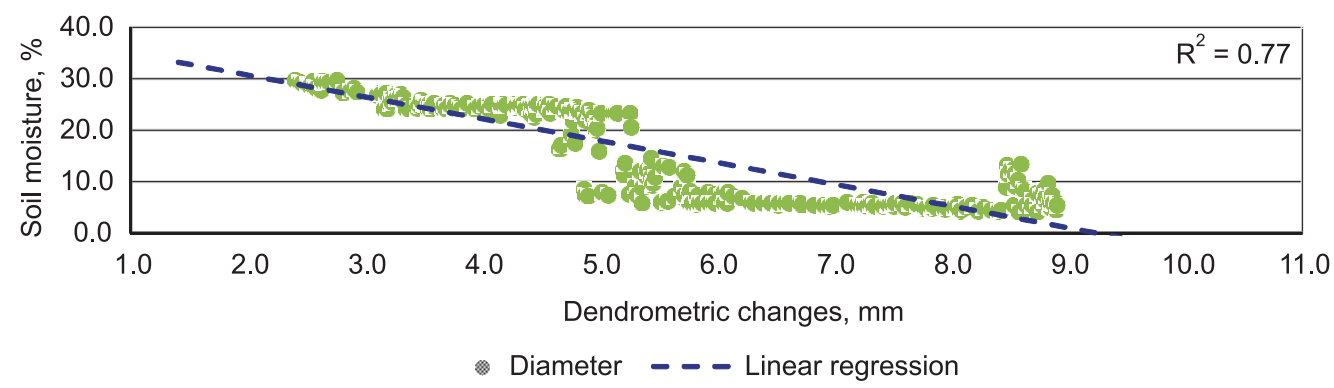

Fig. 10. Dependence of dendrometric changes on soil moisture for 1-day irrigation - maize (Zea Mays L.)

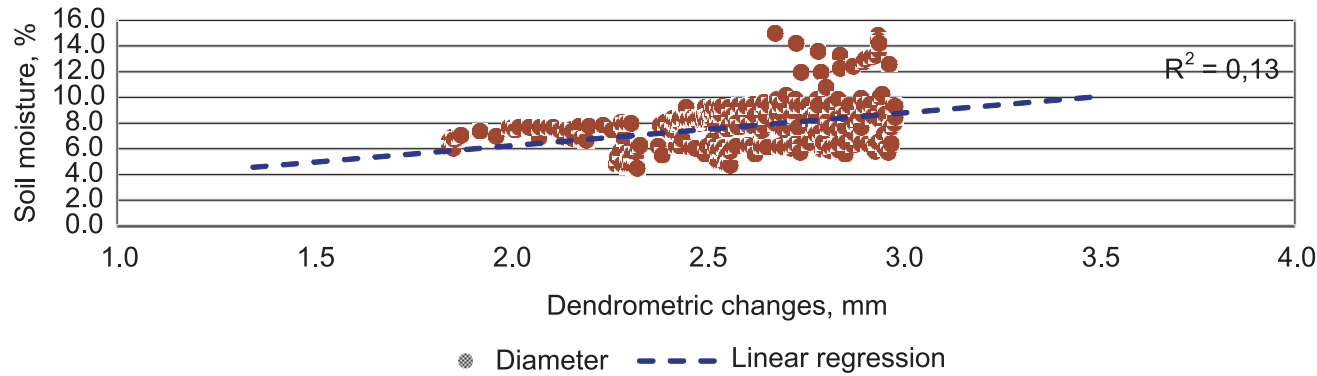

Fig. 11. Dependence of dendrometric changes on soil moisture for 3-day irrigation - maize (Zea Mays L.)

stem as a function of differences in root water uptake and transpiration.

Most of the authors dealt with dendrometric measurements on trees to analyse the reaction of the latter to water deficit. However, few authors have addressed the issue of water deficit on agricultural crops, but they are using different measurement methods to collect data. There are not many studies where authors applied dendrometers to field crops.

An important parameter is also the right time to apply the irrigation dose and the right amount, which needs to be optimized due to climate change and water shortages. With the right timing of irrigation and only the amount needed for plant development, the water does not drain unnecessarily from the root zone to deeper soil profiles. This saves water, but also reduces costs of supplying water to the plants. Zhang et al. (2019) describe impact of using different irrigation intervals. Their experiment was focused on grain yield production of maize in China with 5 variations of the irrigation interval, which can have significant impact of crop production. Ward's (2014) study accounts for economic incentives affecting choices of irrigation technology, crop mix, and water source in the face of water conservation subsidies under various levels of surface water shortage. Findings show that when surface water supplies are reduced, farmers shift to aquifer pumping even when the pumping raises the cost of production or reduces yield. Bienek et al. (2017) proved that the size of the irrigation dose influences the yield of wheat. The grain yield between the control field and the field with the highest irrigation dose increased twofold. Moreover, costs incurred during sprinkling were analysed.

\section{CONCLUSION}

This research showed that different irrigation doses have significant impact to the ability of plants to react to water stress. Even though the plants were grown in laboratory conditions and with the use of soil substrate, the dependence on the application of the same irrigation dose at different intervals in both sunflowers and maize is visible. The irrigation dose of only $5 \mathrm{~mm}$ was chosen due to the frequent occurrence of drought and decreasing precipitation. Nevertheless, a more significant increase in diameter is observed with 1-day irrigation compared to 3-day irrigation: 
$0.8 \mathrm{~mm}$ for sunflower, and $12.0 \mathrm{~mm}$ for maize. The growth of plants mass was continuous at 1-day irrigation with minor fluctuations during the alternation of dark and light phases. During the 3-day irrigation, greater shrinkage of the stems occurred, indicating the onset of water stress in the crops. The results of the work can become the basis for field experiments and for determining the appropriate application of irrigation dose in the conditions of changing climate.

\section{ACKNOWLEDGEMENTS}

This study was supported by the Slovak Research and Development Agency under the contract No. APVV15-0562 and Cultural and Educational Grant Agency under the contract No. KEGA- 047SPU-4/2017.

\section{REFERENCES}

Bieniek, J., Mielnicki, M., Romański, L., Komarnicki, R. (2017). Impact of the Irrigation Dose Amount on the Wheat Yield. Agricultural Engineering, 21(2)

Chitu, E., Sumedrea, D.L., Paltineanu, C., Tanasescu, N. (2012). Daily stem growth pattern in irrigated apple orchard from Arges county in relation to climate change. Fruit growing research. Romania: Research Institute for Fruit Growing Pitesti. 58-77

Čimo, J., Aydın, E., Šinka, K., Tárník, A., Kišš, V., Halaj, P., Toková, L., Kotuš, T. (2020). Change in the Length of the Vegetation Period of Tomato (Solanum lycopersicum L.), White Cabbage (Brassica oleracea L. var. capitata) and Carrot (Daucus carota L.) Due to Climate Change in Slovakia. Agronomy, 10, 1110

Deng, X., Liu, Y., Xu, X., Liu, D, Zhu, G., Yan, X, Wang, Z, Yan, Y. (2018). Comparative proteome analysis of wheat flag leaves and developing grains under water deficit. Frontiers in Plant Science, 9, 425

Diameter Dendrometer small (DD-S). (2020). In Ecomatik. de [online]. (2016). Available at: $\square$ https://ecomatik.de/ en/products/dendrometer/diameter-dd-s/>

ECH2O 10HS. (2020). In Meter environment [online]. 2017 - (2020). Available at: $\square$ https://www.metergroup.com/ environment/products/ech20-10hs-soil-moisture-sensor/>

Elsheikh, E. R. A. (2016). Water productivity of sunflower under different irrigation regimes at Gezira clay soil, Sudan. Leiden: CRC Press/Balkema

Fernández, E., Čermák, J., Cohen, Y., Ferreira, I., Nadezhdina, N., Testi, L., Steppe, K. (2008). Methods to Estimate Sap Flow. ISHS Working Group on Sap Flow. 1-9
Hermann, V., McMahon, S.M., Detto, M., Lutz, J.A., Davies, S. J., Chang-Yang, CH-H., Anderson-Teixeira, K.J. (2016). Tree Circumference Dynamics in Four Forest Characterized Using Automated Dendrometer Brands. PLoS ONE, 11, 12

Hus, M., Paganová, V. (2018). Responses of root system of woody plants to drought. Veda Mladých - Science of Youth 2018, 13, 43-55.

Kumar, S., Sachdeva, S., Bhat, K.V., Vats, S. (2018). Plants responses to drought stress: Physiological, biological and molecular basis. In Biotic and abiotic stress tolerance in plants. Singapore: Springer Singapore, $1-25$

Mars II 900 Full Spectrum Grow Led Light - Mars Hydro. (2020). In Mars-hydro.com [online]. 2020. Available at: $\square$ https://www.mars-hydro.com/>

Mazhayskiy Y.A., Bryś, K., Guseva, T.M., Pavlov, A.A. (2020). The impact of the meteorological factors on the calculation of crops water consumption and vertical moisture exchange in soil. Acta Sci. Pol. Formatio Circumiectus 19(1) 2020, 3-12

Pecho, J. (2020). Klíma na kontinentoch 21. storočia - výrazne teplejšia a suchšia. SHMÚ [cit. 2020-03-15]. Available at: $\square$ http://www.shmu.sk/sk/?page=2049\&id=1041> (in Slovak)

Pecho, J., Markovič, L. (2019). Globálna klíma v rokoch 2015-2019: Klimatická zmena sa zrýchl'uje. SHMÚ. Available at: $\square$ http://www.shmu.sk/sk/?pa$\mathrm{ge}=2049 \& \mathrm{id}=1020>$ (in Slovak)

Švihra, J., Kleňová M. (2011). Biologické základy pestovania záhradníckych rastlín. Nitra: SPU

Szwejkowski, Z., Kuchar, L., Dragańska, E., Cymes, I., Cymes, I. (2017). Current and future agroclimate conditions in Poland in perspective of climate change. Acta Agrophysica. 24(2), 255-364

Uher, A., Andrejiová, A., Bernáth, S., Černý, I., Kóňa, J., Mezey, J., Paulen, O., Valšíková-Frey, M. (2016). Pol'né a záhradné plodiny. Nitra: SPU

Von Känel, L., Fuchs, J., Prasuhn, V., Molnar, P. (2019). Comparison of dendrometer measurements with lysimeter data at Agroscope Reckenholz. 18. Gumpensteiner Lysimetertagung, 143-146

Ward, F.A. (2014). Economic impacts on irrigated agriculture of water conservation programs in drought. Journal of Hydrology 508, 114-127

Zhang, G., Shen., D., Ming, B., Xie, R., Jin, X., Liu, Ch., Hou, P., Xue, J., Chen, J., Zhang, W., Liu, W., Wang, K., Li, Sh. (2019). Using irrigation intervals to optimize water-use efficiency and maize yield in Xinjiang, northwest China. The Crop Journal. 7(3), 322-334 


\section{ZMIANY DENDROMETRYCZNE JAKO WSKAŹNIK STRESU WODNEGO SŁONECZNIKA (HELIANTHUS ANNUS L.) I KUKURYDZY (ZEA MAYS L.) - BADANIA PODSTAWOWE W WARUNKACH LABORATORYJNYCH}

\section{ABSTRAKT}

\section{Cel pracy}

Fizjologiczny wpływ suszy na plony znajduje odzwierciedlenie w zmianach dendrologicznych drzewa lub korpusu rośliny. W przeprowadzonych przez nas badaniach zainstalowaliśmy automatyczne dendrometry i zbadaliśmy wpływ dawki nawadniającej stosowanej w różnych odstępach czasu na wzrost słonecznika i kukurydzy w warunkach laboratoryjnych.

\section{Materiały i metody}

Do badań wybrano słonecznik (Helianthus annus L.) i kukurydzę (Zea Mays L.), wysiane w laboratorium wyposażonym w oświetlenie LED Mars Hydro 400, służące jako zastępcze źródło naturalnego światła słonecznego, aplikowane przez 12 godzin w ciągu doby. Obie uprawy podzielono na kontenery A (gdzie codziennie stosowano dawkę nawadniającą $5 \mathrm{~mm}$ ) i kontenery B (gdzie stosowaną taką samą dawkę nawadniającą, ale w odstępach 3-dniowych). We wszystkich kontenerach mierzono objętościową zawartość wody w glebie za pomocą czujników 10HS (Decagon Devices) oraz prowadzono pomiary dendrometryczne średnicy roślin za pomocą czujników DD-S (Ecomatik).

\section{Wyniki i wnioski}

Porównanie słonecznika i kukurydzy, nawadnianych w różnych odstępach czasu, wykazało większy przyrost średnic łodyg tych roślin przy codziennym nawadnianiu w porównaniu z nawadnianiem w cyklu 3-dniowym: o $0,8 \mathrm{~mm}$ (w przypadku słonecznika) i o $12,0 \mathrm{~mm}$ (w przypadku kukurydzy). Podczas codziennego nawadniania wzrost masy roślinnej był ciagły, z niewielkimi wahaniami podczas naprzemiennych faz ciemności i światła. W uprawach nawadnianych w cyklu 3-dniowym nastąpiło większe obkurczenie łodyg, co świadczy o wystapieniu stresu wodnego roślin. Wyniki pracy mogą posłużyć jako podstawa określenia właściwego zastosowania worków nawadniających w warunkach zmieniającego się klimatu.

Słowa kluczowe: dendrometr, słonecznik, kukurydza, susza, stres wodny 